\title{
Gemcitabine combined with gum mastic causes potent growth inhibition and apoptosis of pancreatic cancer cells
}

\author{
Xin-yu HUANG ${ }^{1, \#, *}$, Hong-cheng WANG ${ }^{1, \#}$, Zhou YUAN ${ }^{1}$, Ang $\mathrm{LI}^{2}$, Mei-lan $\mathrm{HE}^{2}$, Kai-xing Al ${ }^{1}$, Qi ZHENG ${ }^{1}$, Huan-long $\mathrm{QIN}^{1}$ \\ ${ }^{1}$ Department of Surgery, the Sixth People's Hospital, Shanghai Jiaotong University, Shanghai 200233, China; ${ }^{2}$ School of Life Science \\ and Technology, Tongji University, Shanghai 200092, China
}

\begin{abstract}
Aim: To investigate the antiproliferative and apoptotic effects of gemcitabine combined with gum mastic and the underlying mechanisms in human pancreatic cancer cell lines.

Methods: Cell proliferation and apoptosis were examined using the methyl thiazolyl tetrazolium (MTT) assay and propidium iodine staining, respectively. The expression of Bcl-2, Bax, NF-kB p65 subunit, and IkB $\alpha$ protein was measured using Western blotting. Results: Gemcitabine $0.01-100 \mu \mathrm{g} / \mathrm{mL}$ inhibited cell proliferation and induced apoptosis in both pancreatic cancer BxPC-3 and COLO 357 cells. Gum mastic $40 \mu \mathrm{g} / \mathrm{mL}$ significantly potentiated the antiproliferative and apoptotic effects of gemcitabine $10 \mu \mathrm{g} / \mathrm{mL}$ after 72-h treatment. When cells were treated with gemcitabine in combination with gum mastic, the IkB $\alpha$ level was increased, whereas NF-kB activation was blocked; the expression of Bax protein was substantially increased, but Bcl-2 protein was down-regulated. Conclusion: Gemcitabine combined with gum mastic causes potent apoptosis in pancreatic cancer cells. The combination may be an effective therapeutic strategy for pancreatic cancer.
\end{abstract}

Keywords: gemcitabine; gum mastic; pancreatic cancer; apoptosis; NF-kappaB; Bcl-2; Bax

Acta Pharmacologica Sinica (2010) 31: 741-745; doi: 10.1038/aps.2010.54

\section{Introduction}

Pancreatic cancer is the fourth leading cause of cancer death worldwide, with a one-year survival rate of just $10 \%$, and only $5 \%$ of patients survive beyond five years ${ }^{[1]}$. Even after curative resection, the 5 -year survival is only $10 \%-20 \%{ }^{[2]}$. Conventional chemotherapy and radiotherapy, either as single agents or in combination, have limited effect on the overall survival of patients with pancreatic cancer ${ }^{[3]}$. In the past decade, despite the availability of several therapeutic agents, gemcitabine $\left(2^{\prime}, 2^{\prime}\right.$-difluorodeoxycytidine) is still the first-line treatment of locally advanced and metastatic pancreatic cancers ${ }^{[4-8]}$. Gemcitabine has been used as a single antitumor agent or in combination with other cytotoxic agents for solid tumors such as ovarian, non-small cell lung, and pancreatic cancers ${ }^{[9-11]}$. However, the efficiency of gemcitabine is not satisfactory ${ }^{[12,13]}$, and improving its antitumor cytotoxic effects has attracted great interest in recent years.

Gum mastic, a natural resin obtained from the stem and

\footnotetext{
\# These authors contributed equally to the article.

* To whom correspondence should be addressed.

E-mail huangxinyush@hotmail.com

Received 2010-01-03 Accepted 2010-04-03
}

leaves of Pistacia lentiscus trees, has been extensively used for centuries in Mediterranean and Middle Eastern countries, as both a dietary supplement and an herbal remedy. Medical trials show that gum mastic may have cytoprotective or antacid effects on the gastrointestinal system. It has also been reported to possess antioxidant ${ }^{[14]}$ and antibacterial ${ }^{[15]}$ activity. Recently, it has been identified as an effective inhibitor of cell proliferation and cell cycle progression in human prostate cancer cells ${ }^{[16,17]}$ and as an inducer of apoptosis in human HCT116 colon cancer cells ${ }^{[18]}$.

In the present study, we investigated the in vitro antiproliferative and apoptotic effects and mechanisms of gemcitabine combined with gum mastic in human pancreatic cell lines.

\section{Materials and methods \\ Cell culture}

Human pancreatic cell lines BxPC-3 and COLO 357 (American Type Culture Collection, Manassas, VA, USA) were grown in RPMI-1640 and DMEM, respectively, and supplemented with $10 \%$ heat-inactivated fetal bovine serum (FBS) at $37{ }^{\circ} \mathrm{C}$ with $5 \% \mathrm{CO}_{2}$. Cells were passaged twice weekly to ensure exponential growth. 


\section{Cell proliferation assay}

3-(4,5-dimethylthiazol-2-yl)-2,5-diphenyltetrazolium bromide (MTT) assays were performed to evaluate cell growth and viability of cells after treatment with gemcitabine (Lilly, France) and/or gum mastic (Sigma, St Louis, MO, USA, No G0878). Cells were seeded (BxPC-3, $1 \times 10^{4}$ cells/well; COLO 357, $5 \times 10^{4}$ cells/well) in 96-well plates in RPMI-1640 with 10\% FBS for $72 \mathrm{~h}$ at $37^{\circ} \mathrm{C}$ with $5 \% \mathrm{CO}_{2}$. MTT (Sigma Chemicals) reagent (5 $\mathrm{mg} / \mathrm{mL}$ ) was added at the time of evaluation of cell growth, and incubation was continued for an additional $4 \mathrm{~h}$. The reaction was terminated with $150 \mu \mathrm{L}$ dimethylsulfoxide (DMSO, Sigma Chemicals) per well. Absorbance values were determined using an ELISA reader (Model 680, Bio-Rad) at $490 \mathrm{~nm}$.

\section{Analysis of cell apoptosis by flow cytometry}

Cells were seeded $\left(4 \times 10^{5}\right.$ cells per well $)$ in 6 -well plates in RPMI-1640 medium for $24 \mathrm{~h}$. The medium was removed and cells were washed with PBS, and then gemcitabine (10 $\mu \mathrm{g} / \mathrm{mL})$ and/or gum mastic $(40 \mu \mathrm{g} / \mathrm{mL})$ was added. After 48 $\mathrm{h}$, cells were trypsinized and fixed overnight in $70 \%$ ice-cold ethanol at $4{ }^{\circ} \mathrm{C}$. Before flow cytometric analysis, the fixed cells were centrifuged, washed twice with PBS, and resuspended in PI staining solution containing $5 \mu \mathrm{g} / \mathrm{mL}$ PI and $250 \mu \mathrm{g} / \mathrm{mL}$ RNase A (Sigma Chemicals). Using a FACSCalibur flow cytometer (FCM-500, Beckman Coulter), cell cycle analysis was performed on 10000 cells for each sample. Quantitation of cell cycle distribution was performed using CellQuest software.

\section{Western blot analysis}

The cellular lysates were separated by 10\% SDS-PAGE and electro-transferred onto nitrocellulose membranes. After being blocked with 5\% non-fat milk in TBST (20 mmol/L Tris, $150 \mathrm{mmol} / \mathrm{L} \mathrm{NaCl}, 0.2 \%$ Tween-20, pH 7.6), the membranes were incubated with specific anti-NF-kB p65, anti-Bcl-2, antiBax, anti-IKBa or anti- $\beta$-actin (Santa Cruz) antibodies at room temperature for $2 \mathrm{~h}$, and subsequently with 1:4000 horseradish peroxidase (HRP)-conjugated second antibody (Santa Cruz) for $1 \mathrm{~h}$. Immunoreactive bands were visualized using an enhanced chemiluminescence kit (ECL, Santa Cruz Biotechnology Inc, USA). $\beta$-actin was used to normalize the quantity of protein on the blot.

\section{Statistical analysis}

Each experiment was performed at least three times. Data were shown as the mean \pm SD where applicable, and differences were evaluated using Student's $t$-tests. The probability of $P<0.05$ was considered to be statistically significant.

\section{Results}

The effect of gemcitabine and gum mastic on cell proliferation

To detect the effect of gemcitabine and gum mastic on cell growth, human pancreatic cancer cell lines BxPC-3 and COLO 357 were treated with graded concentrations of gemcitabine $(0.01-100 \mu \mathrm{g} / \mathrm{mL})$ or gum mastic $(10-50 \mu \mathrm{g} / \mathrm{mL})$ for $72 \mathrm{~h}$. As shown in Figure 1A, cell proliferation was inhibited by either gemcitabine or gum mastic treatment in a dose-dependent manner. Overall, $10 \mu \mathrm{g} / \mathrm{mL}$ of gemcitabine or $40 \mu \mathrm{g} / \mathrm{mL}$ of gum mastic produced maximal growth inhibition of $55.55 \%$ $(P<0.01)$ and $49.75 \%(P<0.01)$, respectively, in BxPC-3 cells. Treatment of COLO 357 cells with these two agents was also effective. Results from Figure 1A indicate that gum mastic, a natural resin, can inhibit pancreatic cancer cells' growth in vitro. Subsequently, the effect of co-treatment with gemcitabine and gum mastic on cell proliferation using the MTT assay was observed. Cells were cultured in the presence of both $10 \mu \mathrm{g} / \mathrm{mL}$ of gemcitabine and $40 \mu \mathrm{g} / \mathrm{mL}$ of gum mastic for $72 \mathrm{~h}$. After co-treatment with these two agents, cell proliferation was inhibited to a much greater extent than with either agent alone $(P<0.01)$ or control $(P<0.01$, Figure $1 \mathrm{~B})$. These results suggest that gemcitabine combined with gum mastic induces potent growth inhibition.

\section{The effect of gemcitabine and gum mastic on cell apoptosis}

BxPC-3 and COLO 357 cells were treated with gemcitabine (10 $\mu \mathrm{g} / \mathrm{mL})$ and gum mastic $(40 \mu \mathrm{g} / \mathrm{mL})$ individually or in combination. Cell apoptosis was examined by Annexin V-PI doublelabeling and FACS analysis. As shown in Figure 2, in BxPC-3 cells, $30.40 \% \pm 3.477 \%$ and $31.37 \% \pm 1.662 \%$ of cells were apoptotic in the gum mastic group and gemcitabine groups, respectively. In COLO 357 cells, $29.45 \% \pm 1.750 \%$ and $30.07 \% \pm 1.358 \%$ of cells were apoptotic in the two groups. Compared with single-agent treatment, the combination of gemcitabine and gum mastic resulted in apoptosis in a much higher percentage (BxPC-3, 45.13\% $\pm 4.005 \%, P<0.01$; COLO 357, 38.87\% $\pm 4.552 \%$, $P<0.05)$. In contrast, in the control group, induction of apoptosis was not detected (BxPC-3, 5.067\% $\pm 1.365 \%, P<0.01)$. The above results suggest that gemcitabine and/or gum mastic have inhibitory effects on cell apoptosis and growth inhibition, and induction of apoptosis is not cell type specific.

\section{NF-KB activation can be inhibited by combination use of gemcitabine and gum mastic}

Recent reports ${ }^{[19,20]}$ have revealed that, in pancreatic cancer cells, gemcitabine can induce activation of NF-kB. The experiment was repeated and yielded the same results (Figure 3A-3B, lane 2). To detect whether the inhibitory effect of gum mastic on BxPC-3 cell proliferation was caused by the inactivation of NF-kB, Western blotting was performed to test the changes in NF-kB p65 protein expression. As shown in Figure 3B (lane 3), gum mastic alone suppressed NF-kB expression. Most importantly, co-treatment with gum mastic inhibited gemcitabine-induced NF-KB activation (Figure 3B, lane 4). A similar phenomenon was found in COLO 357 cells (Figure 3B).

The treatment of gemcitabine combined with gum mastic downregulated the expression of $\mathrm{Bcl}-2$, increased the expression of Bax, and prevented the degradation of $\mathrm{IKB} \alpha$

Because NF- $\mathrm{kB}$ has a central role in the regulation of the apoptotic pathway in pancreatic cancer, the expression of ІкBa, Bcl-2 (NF-kB downstream anti-apoptotic molecules) and Bax (NF-kB downstream pro-apoptotic molecules) was detected. 
A
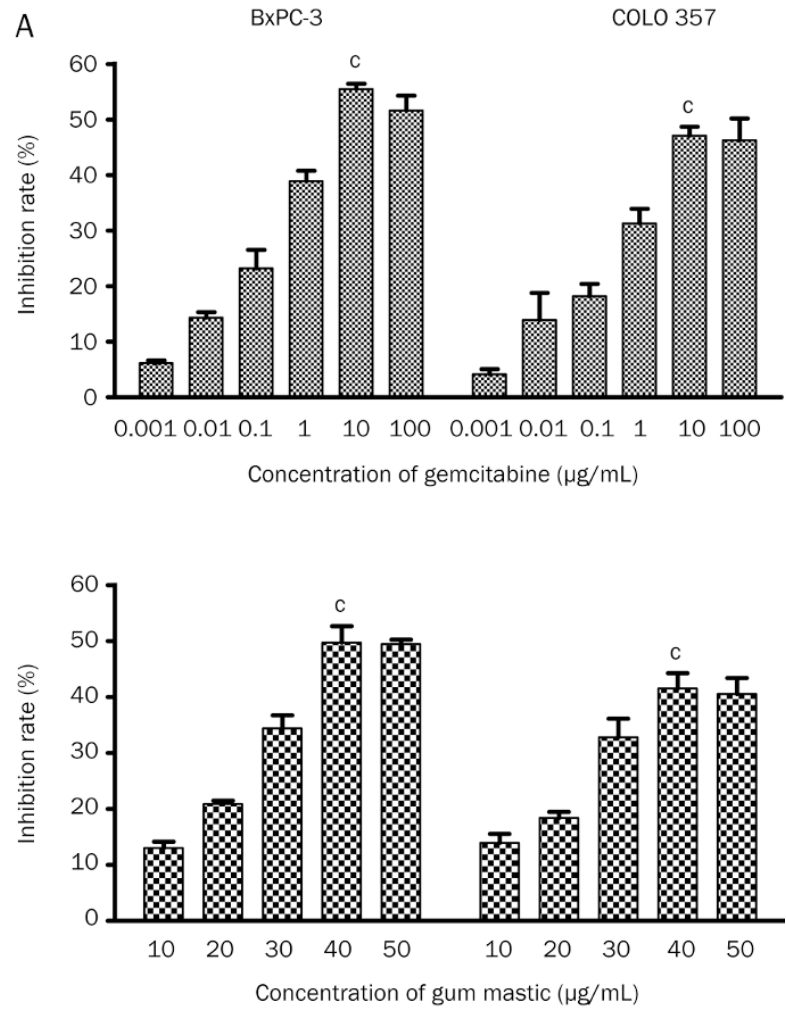

B
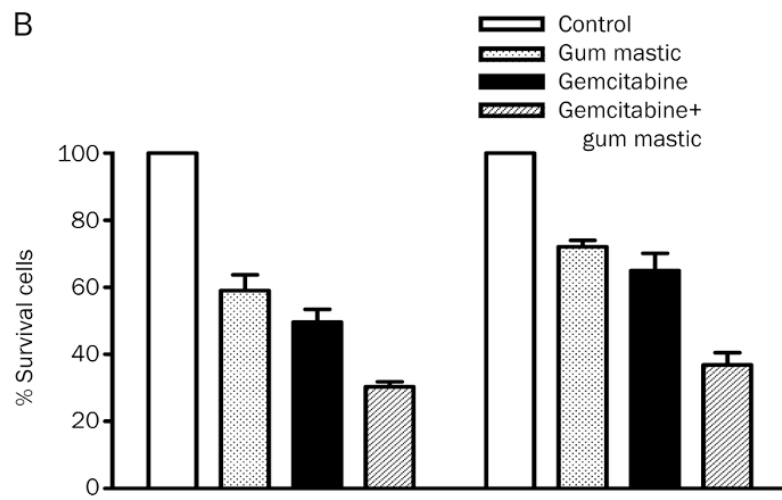

Figure 1. The inhibition of cell proliferation by either gemcitabin $(0.01-100$ $\mu \mathrm{g} / \mathrm{mL}$ ) or gum mastic $(10-50 \mu \mathrm{g} / \mathrm{mL})$ alone $(A)$ or the combination (B). The concentration of gemcitabine $(10 \mu \mathrm{g} / \mathrm{mL})$ and gum mastic $(40 \mu \mathrm{g} / \mathrm{mL})$ used in Figure $1 B$ is based on the result from Figure $1 \mathrm{~A}$. Results are representative of 3 independent experiments. ${ }^{\circ} P<0.01$.

Western blotting showed that the expression of Bcl-2 was significantly down-regulated in the combination group compared to treatment with an individual agent and control $(P<0.01)$, whereas Bax expression was substantially increased. Translocation of NF- $\mathrm{KB}$ to the nucleus is normally regulated by ІкBa degradation. Western blot for IKBa was done as an index of total inhibitor expression levels. When BxPC-3 cells were treated with different concentrations of gemcitabine in the presence or absence of gum mastic for $48 \mathrm{~h}$, significant dose-dependent increases in total IкBa expression levels were observed (Figure 4). A similar effect was observed in COLO

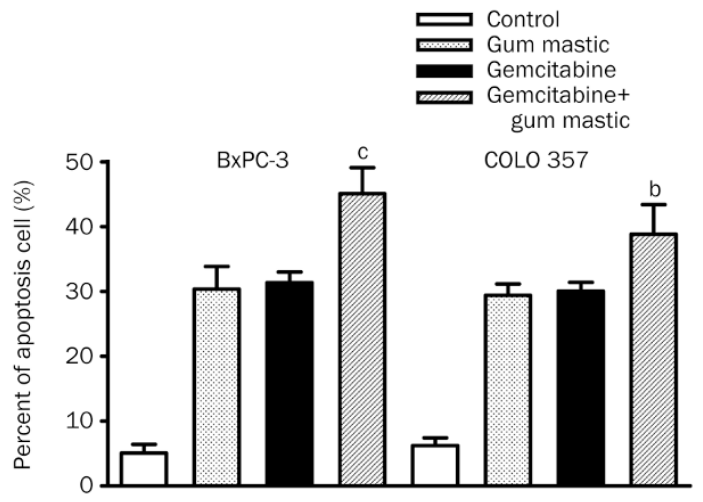

Figure 2. Effect of gemcitabine and gum mastic on cell apoptosis. BxPC$3\left(4 \times 10^{5}\right.$ cells per well) and COLO 357 cells $\left(3 \times 10^{5}\right.$ cells per well) were incubated with either gemcitabine $(10 \mu \mathrm{g} / \mathrm{mL})$ or gum mastic $(40 \mu \mathrm{g} / \mathrm{mL})$ or in combination. After $48 \mathrm{~h}$, cell apoptosis was examined by Annexin V-PI double-labeling and FACS analysis. ${ }^{b} P<0.05,{ }^{c} P<0.01$ vs gemcitabine or gum mastic alone.

357 cells (data not shown).

\section{Discussion}

Over the past decade, the core drug of treatment for locally advanced and metastatic pancreatic cancer has remained gemcitabine $^{[21]}$. However, its efficacy is often limited. To improve its antitumor cytotoxic effect and to identify new treatments for pancreatic cancer treatment, we investigated the effects of gemcitabine in combination with a new agent, gum mastic, on cell proliferation as well as apoptosis in human pancreatic cancer cell lines and explored the mechanism contributing to these effects.

The antitumor activity of a drug is associated with inhibition of tumor cell proliferation, promotion of cellular differentiation, and induction of apoptosis. Gum mastic is a natural extract of Pistacia lentiscus trees, and its anticancer properties are newly identified ${ }^{[16-18,22]}$. In vitro, gum mastic has been proven to inhibit growth of prostate cancer cells and induce apoptosis of colon cancer cells. In this study, we evaluated the effects of gum mastic in pancreatic cancer cells. We found that gum mastic, in vitro, had antiproliferative and apoptotic effects on human pancreatic cancer cells (BxPC-3). Most importantly, gum mastic was synergistic when used with gemcitabine. After simultaneous treatment with these two agents, cell proliferation was greatly suppressed and the rate of cell apoptosis was significantly higher in comparison to cells treated with either agent alone.

NF-kB pathways are key regulators of numerous cellular events such as proliferation, differentiation, and apoptosis, and they are also related to tumor development and progression. Because NF- $\mathrm{kB}$ has a central role in the regulation of apoptotic pathways in pancreatic cancer, we evaluated the effect of gemcitabine combined with gum mastic on expression of the NF-kB upstream molecule IкBa and downstream molecules Bcl-2 and Bax. Mature NF-kB p65:p50 dimers are trapped in the cytoplasm of unstimulated cells by interaction 
A

BxPC-3

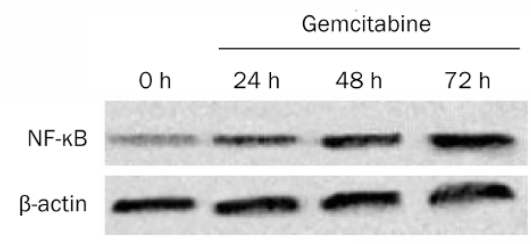

B

$\begin{array}{rl}B \times P C-3 & \\ 3 & 4\end{array}$
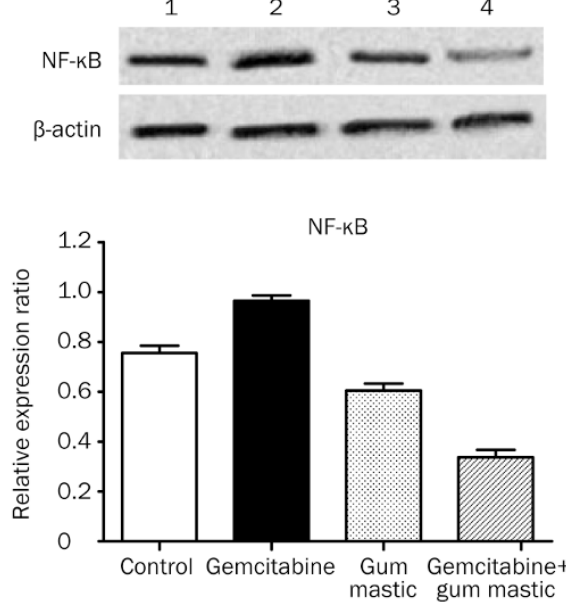

COLO 357

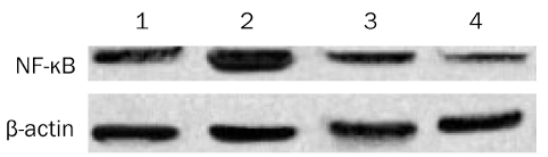

NF-KB

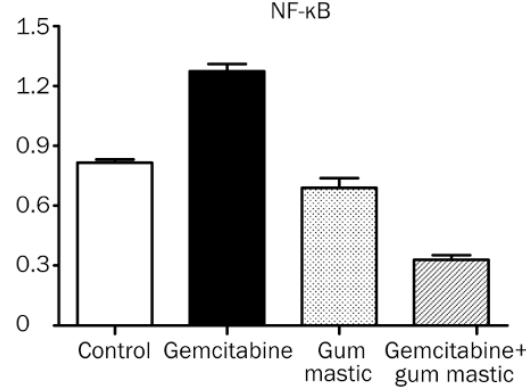

Figure 3. NF-KB activation can be inhibited by combined treatment with gemcitabine and gum mastic. (A)Western blot analysis for NF$\mathrm{KB}$ in nuclear extracts of BxPC-3 cells treated with $10 \mu \mathrm{g} / \mathrm{mL}$ gemcitabine at different time points. (B) Western blot analysis for NF-KB p65 subunit in nuclear extracts of both BXPC-3 and COLO 357 cells after $48 \mathrm{~h}$ treatment with cell medium (lane 1), gum mastic (lane 2), gemcitabine (lane 3) or their combination (lane 4). $\beta$-actin protein was used as an internal control. Densitometric measurement for NF-kB p65 protein levels was normalized to internal control, respectively, and expressed as a relative value.
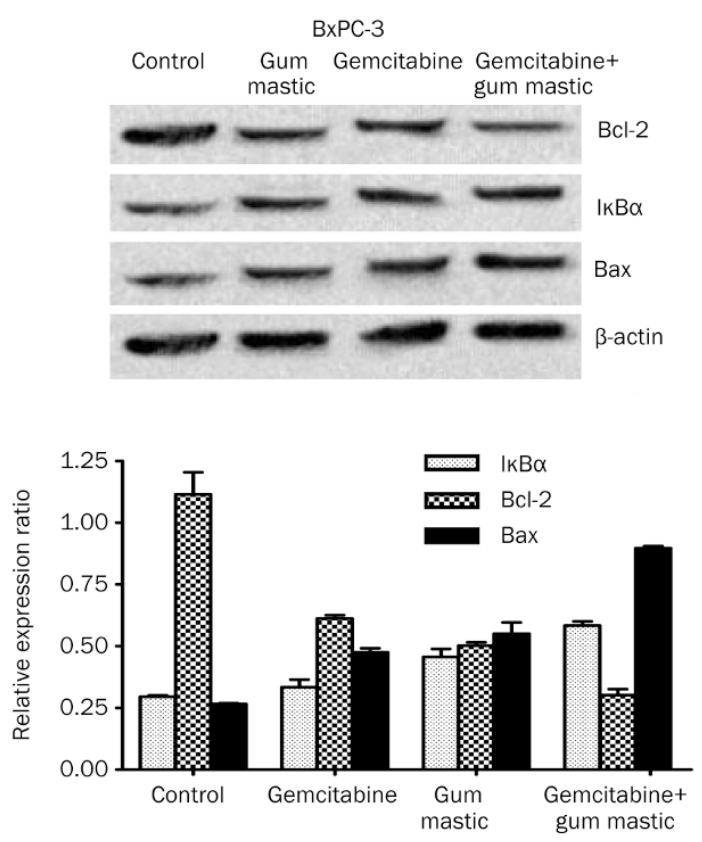

Figure 4. The treatment of gemcitabine combined with gum mastic alters the expression of $\mathrm{Bcl}-2$, Bax, and $\mathrm{IkB} \alpha$. The expression of $\mathrm{Bcl}-2$, $B a x$, and I $\mathrm{KB} \alpha$ was analyzed by Western blot. BxPC-3 cells were treated with cell medium, $40 \mu \mathrm{g} / \mathrm{mL}$ of gum mastic, $10 \mu \mathrm{g} / \mathrm{mL}$ of gemicitabine or their combination for $48 \mathrm{~h}$. $\beta$-actin was used as an internal control. Densitometric measurement for these proteins levels was normalized to internal control, respectively, and expressed as a relative value. with inhibitory proteins termed IкBa. IKK phosphorylates IкBa proteins, thereby targeting them to rapid ubiquitindependent proteolysis that initiates NF-KB activation ${ }^{[23,24]}$. The activation of NF-KB leads to the expression of a large number of target genes, among which are Bcl-2 family proteins. The Bcl-2 family is very important in the regulation of apoptosis and is composed of both pro-apoptotic and anti-apoptotic members ${ }^{[25]}$. It is clear that $\mathrm{Bcl}-2$ protects many cell lines from induced apoptosis. Other proteins, such as $\mathrm{Bcl}-\mathrm{x}_{\mathrm{L}}$, have the same anti-apoptotic function, but several molecules of the same family, such as Bcl-xS and Bax-alpha, can trigger the opposite effect. Bcl-2 can interact with other proteins ${ }^{[26-28]}$. For example, Bax, which can exist as a homodimer, is also able to form a heterodimer with Bcl-2. Overexpression of Bax in several cell lines counteracts the effect of Bcl-2 ${ }^{[25-28]}$.

Similarly, in BxPC-3 and COLO357 cell lines, inhibition of NF-kB by gum mastic was associated with the increased apoptotic effect of gemcitabine. We found that when the cells were treated with gemcitabine and gum mastic, NF-KB p65 expression was strongly suppressed whereas IкBa expression was increased. The expression of Bcl-2 was significantly downregulated and Bax was up-regulated in the combination group compared with individual agent treatment and untreated control. Thus, it can be speculated that the addition of gum mastic to gemcitabine increased the inhibition of the NF-KB signaling pathway on cell growth and apoptosis of BxPC-3 cells. The increased ІкBa expression could inhibit NF-кB expression and activation, which induced cell apoptosis. The inhibition 
of the NF-kB pathway down-regulated anti-apoptotic Bcl-2 but up-regulated the expression of pro-apoptotic Bax.

Therefore, gemcitabine combined with gum mastic leads to potent suppression of pancreatic cancer cell proliferation and apoptosis. However, whether it is a common phenomenon should be determined by testing more pancreatic cell lines such as PANC-1 $1^{[29,30]}$. Our findings suggest that the combined use of gemcitabine and gum mastic has potential clinical value and may act as an effective therapeutic strategy for the clinical management of pancreatic cancer.

\section{Author contribution}

Xin-yu HUANG supervised the project and designed the experiments; Hong-cheng WANG, Zhou YUAN, Ang LI, Mei-lan HE, and Kai-xing AI performed the experiments; Qi ZHENG and Huan-long QIN wrote the paper; Ang LI critical revised the manuscript.

\section{References}

1 Fryer RA, Galustian C, Dalgleish AG. Recent advances and developments in treatment strategies against pancreatic cancer. Curr Clin Pharmacol 2009; 4: 102-12.

2 Yokoyama Y, Nimura Y, Nagino M. Advances in the treatment of pancreatic cancer: limitations of surgery and evaluation of new therapeutic strategies. Surg Today 2009; 39: 466-75.

3 Lockhart AC, Rothenberg ML, Berlin JD. Treatment for pancreatic cancer: current therapy and continued progress. Gastroenterology 2005; 128: 1642-54.

4 Burris HA, Moore MJ, Andersen J, Green MR, Rothenberg ML, Modiano MR, et al. Improvements in survival and clinical benefit with gemcitabine as first-line therapy for patients with advanced pancreatic cancer: a randomized-trial. J Clin Oncol 1997; 15: 2403-13.

5 Burris HA, Storniolo AM. Assessing clinical benefit in the treatment of pancreas cancer: gemcitabine compared to 5-fluorouracil. Eur J Cancer 1997; 33: 18-22.

6 Mackenzie RP, McCollum AD. Novel agents for the treatment of adenocarcinoma of the pancreas. Expert Rev Anticancer Ther 2009; 9: 1473-85.

7 Igarashi H, Ito T, Kawabe K, Hisano T, Arita Y, Kaku T, et al. Chemoradiotherapy with twice-weekly administration of low-dose gemcitabine for locally advanced pancreatic cancer. World J Gastroenterol 2008; 14: 5311-5.

8 Boeck S, Hinke A, Wilkowski R, Heinemann V. Importance of performance status for treatment outcome in advanced pancreatic cancer. World J Gastroenterol 2007; 13: 224-7.

9 Abratt RP, Bezwoda WR, Falkson G, Goedhals L, Hacking D, Rugg TA. Efficacy and safety profile of gemcitabine in non-small cell lung cancer. Phase II study. J Clin Oncol 1994; 12: 1535-40.

10 Lund B, Hansen OP, Theilade K, Hansen M, Neijit JP. Phase II study of gemcitabine $\left(2^{\prime}, 2^{\prime}\right.$-difluorodeoxycytidine) in previously treated ovarian cancer patients. J Natl Cancer Inst 1994; 86: 1530-3.

11 Heinemann V. Gemcitabine: progress in the treatment of pancreatic cancer. Oncology 2001; 60: 8-18.
12 Nieto J, Grossbard ML, Kozuch P. Metastatic pancreatic cancer 2008: is the glass less empty? Oncologist 2008; 13: 562-76.

13 Custodio A, Puente J, Sastre J, Díaz-Rubio E. Second-line therapy for advanced pancreatic cancer: a review of the literature and future directions. Cancer Treat Rev 2009; 35: 676-84.

14 Dedoussis GV, Kaliora AC, Psarras S, Chiou A, Mylona A, Papadopoulos NG, et al. Antiatherogenic effect of Pistacia lentiscus via GSH restoration and downregulation of CD36 mRNA expression. Atherosclerosis 2004; 174: 293-303.

15 Huwez FU, Thirlwell D, Cockayne A, Ala'Aldeen DA. Mastic gum kills Helicobacter pylori. N Engl J Med 1998; 339: 1946.

16 He ML, Yuan HQ, Jiang AL, Gong AY, Chen WW, Zhang PJ, et al. Gum mastic inhibits the expression and function of the androgen receptor in prostate cancer cells. Cancer 2006; 106: 2547-55.

17 He ML, Li A, Xu CS, Wang SL, Zhang MJ, Gu H, et al. Mechanisms of antiprostate cancer by gum mastic: NF-kappaB signal as target. Acta Pharmacol Sin 2007; 28: 446-52.

18 Balan KV, Demetzos C, Prince J, Dimas K, Cladaras M, Han Z, et al. Induction of apoptosis in human colon cancer HCT116 cells treated with an extract of the plant product, Chios mastic gum. In Vivo 2005; 19: 93-102.

19 Li Y, Ellis KL, Ali S, El-Rayes BF, Nedeljkovic-Kurepa A, Kucuk O, et al. Apoptosis-inducing effect of chemotherapeutic agents is potentiated by soy isoflavone genistein, a natural inhibitor of NF-KB in BxPC-3 pancreatic cancer cell line. Pancreas 2004; 4: 90-5.

20 Banerjee S, Zhang YX, Ali S, Bhuiyan M, Wang ZW, Chiao PJ, et al. Molecular evidence for increased antitumor activity of gemcitabine by genistein in vitro and in vivo using an orthotopic model of pancreatic cancer. Cancer Res 2005; 65: 9064-72.

21 O'Reilly EM. Pancreatic adenocarcinoma: new strategies for success. Gastrointest Cancer Res 2009; 3: S11-5.

22 Dimas K, Hatziantoniou S, Wyche JH, Pantazis P. A mastic gum extract induces suppression of growth of human colorectal tumor xenografts in immunodeficient mice. In Vivo 2009; 23: 63-8.

23 Baltimore D, Beg AA. DNA-binding proteins. A butterfly flutters by. Nature 1995; 373: 278-87.

24 Gilmore TD, Koedood M, Piffat KA, White DW. Rel/NF-kappaB/ IkappaB proteins and cancer. Oncogene 1996; 13: 1367-78.

25 Boise LH, Gottschalk AR, Quintáns J, Thompson CB. Bcl-2 and Bcl-2related proteins in apoptosis regulation. Curr Top Microbiol Immunol 1995; 200: 107-21.

26 Korsmeyer SJ, Shutter JR, Veis DJ, Merry DE, Oltvai ZN. Bcl-2/Bax: a rheostat that regulates an anti-oxidant pathway and cell death. Semin Cancer Biol 1993; 4: 327-32.

27 Chao DT, Korsmeyer SJ. BCL-2 family: regulators of cell death. Annu Rev Immunol 1998; 16: 395-419.

28 Fahy BN, Schlieman MG, Mortenson MM, Virudachalam S, Bold RJ. Targeting BCL-2 overexpression in various human malignancies through NF-KB inhibition by the proteasome inhibitor bortezomib. Cancer Chemother Pharmacol 2005; 56: 46-54.

29 Jiang PH, Motoo Y, Sawabu N, Minamoto T. Effect of gemcitabine on the expression of apoptosis-related genes in human pancreatic cancer cells. World J Gastroenterol 2006; 12: 1597-602.

30 Johnson SK, Haun RS. Insulin-like growth factor binding protein-5 influences pancreatic cancer cell growth. World J Gastroenterol 2009; 15: $3355-66$. 